SIR,-I am glad that Bowes et al. (1966) now observe the agreement on three principal points between Bowes et al. (1964) and O'Hara (1961, pp. 272-275). Much of the remaining field of conflict between our views concerns contradictory reading of the field evidence and cannot be resolved by further discussion, but Bowes et al. (1966) have raised three points worthy of remark.

(i) Their comments on the occurrence of isolated masses of ultrabasic or garnetiferous basic gneiss in the country rocks are covered by my earlier remarks (O'Hara, 1961, p. 272, 1. 26-33 and p. 275, 1. 4-9).

(ii) They suggest that data in Cooper (1936) throw doubt on the usefulness of criteria for composition variation in adjacent layers of igneous complexes used by O'Hara (1965). The three samples in question were gathered at three different localities up to five miles apart, and I doubt if they are relevant to discussions of the chemistry of adjacent layers.

(iii) The ten analysed samples from the Loch an Daimh Mhor mass (O'Hara, 1961, table 3, and figs. 3, 4,5) came from successive layers of two contiguous specimens collected from a well exposed lower contact of the lower serpentinite layer (location given by O'Hara $(1961$, p. 249) and deducible from O'Hara (1965, fig. 1B and p. 297). Neither indifferent exposure nor alleged juxtaposition of igneous rocks and country rocks can explain away the geochemical sequence, the principal features of which (rapid increase of $\mathrm{Fe} / \mathrm{Mg}$ ratio at relatively low $\mathrm{Ca} / \mathrm{Ca}+\mathrm{Mg}+\mathrm{Fe}$ ratio) is reproduced by 8 analyses of materials from five different masses (these samples being chosen as representing good samples of the principal petrographic types involved in the masses). The dissimilarity between these trends and those revealed by alpine-type ultrabasic masses and a layered igneous complex (Bowes $e t$ al. 1966, fig. 1) strengthens my case that the basic gneisses are not related to the ultrabasic gneisses by an igneous mechanism. The fact that data collected by Bowes et al. (1966, fig. 1) over a much wider area define a composition " field" which does not include 8 out of 18 samples chosen for analysis by O'Hara (1961) suggests that Bowes et al's. sampling is less, not more, comprehensive than mine.

Grant InstTtute of Geology,

M. J. O'HARA.

UNIVERSITY OF EDINBURGH.

April, 1966.

\title{
CLOUDED FELSPAR
}

SIR,-The recent demonstration that clouded felspar in the dykes from the Scourie district contains more water than unclouded felspar from the same rocks (Burns, 1966) is of considerable interest, and would appear to have a petrogenetic significance outside the metamorphosed rocks in which it has been described.

Black felspars occur in several geological environments in South Greenland, as constituents of charnockites, as primary minerals in andesitic dykes formed under regional metamorphic conditions, and as primary plagioclases in unmetamorphosed alkali gabbros of the Gardar igneous province. Only the black felspars from the last environment have been investigated in any detail.

Black felspars occur in the Gardar alkali gabbro dykes as giant megacrysts, some of which reach $30-40 \mathrm{~cm}$. in length. They are commonly rimmed by clear felspar which has apparently formed from the black felspar by loss of colour during interaction with their basic hosts. It is thought significant that black felspars taken from hosts in which primary hornblende crystallized do not show the clear rims. The black and clear felspars show very similar properties except for colour; they are integral parts of the same crystals, twin planes crossing from one part of the crystal to another with no break at the border between the two colour varieties. The chemical composition of the two types is identical with respect to the major elements. However, water is significantly more abundant in the black felspar than in the clear. 
The dark felspars show no resolvable inclusions using either a normal microscope or a phase contrast microscope; preliminary investigations using an electron microscope revealed areas showing considerable structural defects within the black felspar but no sign of a separate mineral phase. Chemical analyses showed the two felspars to contain approximately the same amount of iron $(0.3 \% \mathrm{Fe})$. However measurements of the magnetic susceptibility of the two types of felspar showed that the clear felspar was for all practical purposes unmagnetic while the black felspar was quite markedly paramagnetic with a susceptibility similar to olivine.

Thermogravimetric studies, using the method described by Micheelsen (in press) showed that the black felspar contains $2,250 \mathrm{ppm}$ of water while the clear felspar contains $790 \mathrm{ppm}$ water. Most of the water in the black felspar $(1,800 \mathrm{ppm})$ is believed to be held as $\mathrm{Si}-\mathrm{OH}$ groups as it is given off in the temperature range $150^{\circ}$ to $550^{\circ} \mathrm{C}$. In contrast the water in the clear felspar appears to be approximately equally divided between water as $\mathrm{H}_{2} \mathrm{O}$ given off below $200^{\circ} \mathrm{C}$ and water as $\mathrm{Si}-\mathrm{OH}$ groups.

The coloration and magnetic properties of the felspar persist to above $800^{\circ} \mathrm{C}$ after the bulk of the water has been given off from the felspar. Between $800^{\circ} \mathrm{C}$ and $1200^{\circ} \mathrm{C}$ both clear and black felspar increase slightly in weight during heating; this increase is thought to be due to oxidation of the iron present. It is thought significant that the increase in weight found in the clear felspar is three times as large as that found in the black. Since this increase in weight takes place in the same temperature range as the loss in colour and magnetic properties it is suggested that the state of iron in the felspar is the main controlling factor in the abnormal properties of the black felspar. This in turn may be controlled by the amount of water present during the initial formation of the felspar.

In the case of the megacrysts found in the Greenland rocks it is suggested that the coloration is due to the crystallization of felspar in a water-rich environment which affected the structural state of the traces of iron present. Later inclusion of the megacrysts in a more anhydrous magma drove off the water and changed the structural state of the iron. Analogous processes may have taken place during the formation of the black felspars in the Scourie dykes, having occurred either in the late magmatic stages of the history of the dykes or at a later stage. It is of interest that felspars from the Scourie dykes resemble those from the Gardar rocks in containing " submicroscopic inclusions" (MacGregor, 1931) in contrast to the majority of clouded felspar in which the inclusions are readily seen using normal techniques.

\section{REFERENCES}

BURNS, D. J., 1966. Chemical and mineralogical changes associated with the Laxford metamorphism of dolerite dykes in the Scourie-Loch Laxform area, Sutherland, Scotland. Geol. Mag., 103, 19-35.

MacGregor, A. G., 1931. Clouded felspars and thermal metamorphism. Mineralog. Mag., 22, 524-38.

MicheelseN, H., in press. The structure of dark flint from Stevns, Denmark. Medd. dansk geol. Foren. 16, 286-395.

Grønlands Geologiske UNDERsøgelse,

D. Bridgwater,

ØSTERVOLDGADE 5-7,

KøBENHAVN K,

DENMARK.

25th April, 1966. 